\title{
The complete mitochondrial DNA sequence of the pantropical earthworm Pontoscolex corethrurus (Rhinodrilidae, Clitellata): Mitogenome characterization and phylogenetic positioning
}

\author{
Ana C. Conrado', Hugo Arruda 2 , David W.G. Stanton³, Samuel W. James ${ }^{4}$, \\ Peter Kille ${ }^{3}$, George Brown ${ }^{5}$, Elodie Silva ${ }^{5}$, Lise Dupont ${ }^{6}$, Shabnam Taheri ${ }^{6}$, \\ Andrew J. Morgan ${ }^{3}$, Nelson Simóes ${ }^{2}$, Armindo Rodrigues ${ }^{7}$, \\ Rafael Montiel ${ }^{8}$, Luis Cunha ${ }^{3,5}$
}

I Universidade Federal do Paraná, Departamento de Ciências do Solo, Curitiba, Paraná, Brazil 2 CIRN/ Departamento de Biologia, Universidade dos Açores, Ponta Delgada, Portugal 3 Cardiff School of Biosciences, Cardiff University, Museum Avenue, Cardiff, UK CF10 3AX 4 Maharishi University of Management, Sustainable Living Dept., Fairfield, IA, USA 5 EMBRAPA-Florestas, Empresa Brasileira de Pesquisa Agropecuária (Embrapa), Colombo, PR, Brazil $\mathbf{6}$ Université Paris Est Créteil, Institut d'écologie et des sciences de l'environnement de Paris (IEES), Créteil, France 7 Centro de Vulcanologia e Avaliação de Riscos Geológicos (CVARG), Universidade dos Açores, Ponta Delgada, Portugal 8 Laboratorio Nacional de Genómica para la Biodiversidad, Unidad de Genómica Avanzada, Centro de Investigación y de Estudios Avanzados del Instituto Politécnico Nacional, Irapuato, México

Corresponding author: Luis Cunha (luisnevescunha@gmail.com)

Academic editor: F. Govedich | Received 16 May 2017 | Accepted 17 July 2017 | Published 8 August 2017

http://zoobank.org/85EC475D-CAF6-455A-8B4F-A68EF853E5E9

Citation: Conrado AC, Arruda H, Stanton DWG, James SW, Kille P, Brown G, Silva E, Dupont L, Taheri S, Morgan AJ, Simôes N, Rodrigues A, Montiel R, Cunha L (2017) The complete mitochondrial DNA sequence of the pantropical earthworm Pontoscolex corethrurus (Rhinodrilidae, Clitellata): Mitogenome characterization and phylogenetic positioning. ZooKeys 688: 1-13. https://doi.org/10.3897/zookeys.688.13721

\begin{abstract}
Pontoscolex corethrurus (Müller, 1857) plays an important role in tropical soil ecosystems and has been widely used as an animal model for a large variety of ecological studies, in particular due to its common presence and generally high abundance in human-disturbed tropical soils. In this study we describe the complete mitochondrial genome of the peregrine earthworm $P$. corethrurus. This is the first record of a mitochondrial genome within the Rhinodrilidae family. Its mitochondrial genome is $14835 \mathrm{bp}$ in length containing 37 genes (13 protein-coding genes (PCG), 2 rRNA genes and 22 tRNA genes). It has the same gene content and structure as in other sequenced earthworms, but unusual among invertebrates it has
\end{abstract}

Copyright Ana C. Conrado et al. This is an open access article distributed under the terms of the Creative Commons Attribution License (CC BY 4.0), which permits unrestricted use, distribution, and reproduction in any medium, provided the original author and source are credited. 
several overlapping open reading frames. All genes are encoded on the same strand. Most of the PCGs use ATG as the start codon except for ND3, which uses GTG as the start codon. The A+T content of the mitochondrial genome is $59.9 \%(31.8 \% \mathrm{~A}, 28.1 \% \mathrm{~T}, 14.6 \% \mathrm{G}$, and $25.6 \%$ for $\mathrm{C})$. The annotated genome sequence has been deposited in GenBank under the accession number KT988053.

\section{Keywords}

Pontoscolex corethrurus, mitochondria, mitochondrial genome, Rhinodrilidae, earthworm, Azores, peregrine species

\section{Introduction}

Excluding a few aquatic taxa, earthworms (Annelida: Clitellata) are mostly terrestrial and include ca. 5,500 species (Blakemore et al. 2006). Believed to have originated in the Guyana Shield (Righi 1984), the earthworm Pontoscolex corethrurus (Müller, 1857) is a globally distributed species found in most tropical regions. It mainly occurs in humandisturbed areas and can be used as an indicator of ecosystem disturbance (Brown et al. 2006), and is commonly used in ecotoxicological studies (e.g. Buch et al. 2011; Buch et al. 2013; Da Silva et al. 2016). The species formerly belonged in the Glossoscolecidae family, but was recently allocated to the Rhinodrilidae family by James (2012), following the phylogeny of James and Davidson (2012). It is also the most well-known earthworm species in the humid tropics, frequently used in ecological and agronomic studies (Bhattacharjee and Chaudhuri 2002; Buch et al. 2013; Chapuis-Lardy et al. 2010; Dupont et al. 2012; Hamoui 1991; Marichal et al. 2010). Being a geophagous endogeic species, $P$. corethrurus shows high plasticity regarding its tolerance to soil physicochemical characteristics, including variable moisture, high temperatures, exceptionally high carbon dioxide and low oxygen levels, and is capable of inhabiting nutrient-poor soils (Cunha et al. 2014; Hamoui 1991; Lavelle et al. 1987), as well as rotten logs (Buch et al. 2011).

Molecular data have become increasingly important in recent years. In animals, the mitochondrial DNA (mtDNA) typically contains 37 genes, encoding 13 proteins for the enzymes required for oxidative phosphorylation, the two ribosomal RNA units (rRNA), and 22 transfer RNAs (tRNAs) necessary for the translation of the proteins encoded by $\mathrm{mtDNA}$ (Anderson et al. 1981; Boore 1999; Zhao et al. 2015). Remarkable progress has been made over the past several years in the field of the molecular systematics of annelids. Compared with individual genes, the mitochondrial genome is still a promising tool for inferring phylogenetic relationships due to its high content of information, and has been applied in some phylogenetic studies involving earthworms (Zhang et al. 2015; Zhang et al. 2016b).

In this study, we sequenced the complete mtDNA sequence of $P$. corethrurus for the first time and analyzed its structure. Additionally, we conducted phylogenetic analyses based on the mitochondrial sequence data available elsewhere with the purpose of investigating the phylogenetic position of $P$. corethrurus within Clitellata. The information reported in this article will facilitate further investigations of phylogenetic relationships of different Annelida species. 


\section{Material and methods}

\section{Sample collection and DNA extraction}

A group of clitellate (adult) P. corethrurus was collected in São Miguel Island (Azores, Portugal) inside pineapple greenhouses (Locality: Fajã de Baixo, 37²5'12.2"N, $\left.25^{\circ} 38^{\prime} 21.3^{\prime \prime W}\right)$ during January 2015 . Animals were euthanized in $10 \%$ ethanol and preserved in $96 \%$ ethanol for later work. A piece of body wall tissue was used for genomic DNA extraction using standard phenol/chloroform (Sambrook and Russell 2001) procedure followed by ethanol precipitation and kept at $4^{\circ} \mathrm{C}$ for subsequent use.

\section{Mitochondrial DNA amplification}

The complete $P$. corethrurus mitogenome was amplified using seven sets of primers (Table 1) designed based on sequences retrieved from a previous study (Cunha et al. 2014).

Long PCR targets were amplified using different combinations of the primer sets, and initially sequenced with the same forward or reverse primers. Subsequent primer walking method was used to close the sequencing gaps. To ensure the accuracy of the sequence, every two contiguous segments overlapped by at least $80 \mathrm{bp}$. PCRs were performed using $-40 \mathrm{ng}$ of DNA and $0.4 \mu \mathrm{M}$ forward and reverse primers, $0.2 \mathrm{mM}$ dNTP mix and 1.25 U Platinum HiFi DNA polymerase buffered with $1 \mathrm{X}$ Mg-free buffer (Thermofisher Scientific, UK). PCR amplification buffer was supplemented with $\mathrm{MgCl}_{2}$ to achieve a final concentration of $1.75 \mathrm{mM}$ in a total volume of $25 \mu \mathrm{l}$ reaction mixture. The reaction was denatured at $95^{\circ} \mathrm{C}$ for $3 \mathrm{~min}$, cycled 35 times at $95^{\circ} \mathrm{C}$ for $30 \mathrm{~s}, 30 \mathrm{~s}$ at the required primer annealing temperature and $72^{\circ} \mathrm{C}$ for $1 \mathrm{~min}$ per 1000 bp depending on target fragment length. Negative controls were included in all PCR amplifications to confirm the absence of contaminants. Before sequencing, PCR cleanups were performed using Exo-SAP-IT (Amersham Pharmacia, UK) reagents. Exonuclease $1(0.25 \mu \mathrm{l})$ and Shrimp Alkaline Phosphatase $(0.5 \mu \mathrm{l})$ were mixed with the PCR product $(10 \mu \mathrm{l})$ and incubated at $37^{\circ} \mathrm{C}$ for $45 \mathrm{~min}$ followed by $80^{\circ} \mathrm{C}$ for 15 min. DNA was sequenced using ABI PRISM BigDye v3.1 Terminator Sequencing technology (Applied Biosystems, USA) on an ABI PRISM 3100 DNA automated Sequencer.

\section{Sequence editing and analysis}

Sequence trace files were corrected and aligned with the MEGA v.7 (Kumar et al. 2016). The sequence overlap and mitogenome assembly were performed using CLC main workbench v.6 (Qiagen). The annotation of the 13 protein-coding genes and two rRNA genes were determined using the MITOS v.2 web server (Bernt et al. 2013) and 
Table I. Details of the primers used to amplify the mitochondrial DNA of $P$. corethrurus.

\begin{tabular}{c|c|c|c|c|}
\hline Primer code & Orientation & $\begin{array}{c}\text { Annealing } \\
\text { position } \mathbf{( b p})\end{array}$ & Nucleotide sequence $\left(5^{\prime}-3^{\prime}\right)$ & $\begin{array}{c}\text { Melting } \\
\text { Temperature }\left({ }^{\circ} \mathbf{C}\right)\end{array}$ \\
\hline FP_1 & Forward & $2154 . .2175$ & CTCTACTATGTACCCAGGAGTG & 57.46 \\
\hline RP_1 & Reverse & $2758 . .2775$ & GCGGCCAAGATAAAGCAC & 57.67 \\
\hline RP_2 & Reverse & $3740 . .3762$ & TAGAGGCGGTAAGGAGAAAGTAT & 58.61 \\
\hline RP_3 & Reverse & $5691 . .5708$ & CAGAGGCGAGGTAAATTC & 53.85 \\
\hline RP_4 & Reverse & $6356 . .6373$ & TGTTCAGGGCTAGGATTG & 54.99 \\
\hline FP_5 & Forward & $7983 . .8004$ & ACTAGTGTCACTTACAACAACC & 57.16 \\
\hline RP_5 & Reverse & $8649 . .8670$ & TGATAAGGGGGAAAGTCTGATC & 56.84 \\
\hline FP_6 & Forward & $8766 . .8787$ & AGTAGCCGCTATAATAGTCCTT & 57.91 \\
\hline RP_6 & Reverse & $10328 . .10349$ & TGATTTGGGGTCAGAGCCGTAG & 61.59 \\
\hline FP_7 & Forward & $10459 . .10478$ & AAAGCTTGGCGGTGCTTCAC & 63.23 \\
\hline RP_7 & Reverse & $11242 . .11263$ & CCTAGTGTGTGTCAGGACGCTT & 64.75 \\
\hline
\end{tabular}

Table 2. Representative Clitellata species included in this study for comparison.

\begin{tabular}{l|c|c|c}
\hline \multicolumn{1}{c|}{ Species } & Family & Length (bp) & GenBank accession number \\
\hline Pontoscolex corethrurus & Rhinodrilidae & 14,835 & Present study \\
\hline Tonoscolex birmanicus & Megascolecidae & 15,170 & KF425518 \\
\hline Amynthas gracilis & Megascolecidae & 15,161 & NC_027258 \\
\hline Duplodicodrilus schmardae & Megascolecidae & 15,156 & NC_029867 \\
\hline Metaphire guillemi & Megascolecidae & 15,174 & NC_029869 \\
\hline Perionyx excavatus & Megascolecidae & 15,083 & NC_009631 \\
\hline Lumbricus terrestris & Lumbricidae & 14,998 & NC_001673 \\
\hline Drawida japonica & Moniligastridae & 14,648 & NC_028050 \\
\hline Hirudo nipponia & Hirudinidae & 14,414 & NC_023776 \\
\hline
\end{tabular}

manually curated using other published annelid mitogenomes as shown in Table 2, whereas the tRNA genes were identified using the program tRNAscan-SE 1.21 (Lowe and Eddy 1997). The annotated genome sequence was deposited in GenBank under accession number KT988053.

\section{Phylogenetic analyses}

To clarify the phylogenetic position of $P$. corethrurus within the Clitellata, the complete mitogenome sequences of eight representative Clitellata species (Table 2) were incorporated together with the presently obtained $P$. corethrurus mitogenome sequence for phylogenetic analysis. Phylogenetic analyses were based on 13 protein-coding genes and the two rRNA units, which were aligned separately using MEGA v.7 (Kumar et al. 2016) with minor manual adjustments and then concatenated. The possible bias of substitution saturation at each codon position of protein-coding genes and two rRNA genes was investigated using DAMBE v.4.5.57 (Xia and Xie 2001) and MEGA v. 7 (Kumar et al. 2016). 
Two different methods, Bayesian inference (BI) and maximum likelihood (ML) were used to construct the phylogenetic tree. Bayesian analyses were undertaken with MrBayes v.3.1.2 (Ronquist and Huelsenbeck 2003) under the best-fit model of nucleotide evolution selected in MrModeltest v.2.3 (Nylander 2004), using the Assignment Index Criterion (AIC). Analyses were run for 1,000,000 generations, and sampled every 100 generations to assess convergence. Trees that produced non-stationary log-likelihood values were discarded as part of a burn-in procedure and combined the remaining trees that resulted in convergent log-likelihood scores from both independent searches. These trees were used to construct a consensus tree.

Maximum likelihood analysis (ML) was performed with MEGA v.7 (Kumar et al. 2016). Initial tree(s) for the heuristic search were obtained automatically by applying Neighbour-Joining and BioNJ algorithms to a matrix of pairwise distances estimated using the Maximum Composite Likelihood (MCL) approach and then selecting the topology with superior log likelihood value. A discrete Gamma distribution was used to model evolutionary rate differences among sites $(5$ categories $(+\mathrm{G}$, alpha parameter $=$ $0.9143)$ ). The rate variation model allowed for some sites to be evolutionarily invariable ([+I], 17.7596\% sites). The analysis involved nine mitogenome sequences (Table 2). All positions containing gaps and missing data were eliminated. The bootstrap consensus tree inferred from 1000 replicates was taken to represent the evolutionary history of the taxa analysed (Felsenstein 1985).

\section{Results and discussion}

\section{Mitochondrial genomic structure}

The mitochondrial genome of $P$. corethrurus was determined to be $14835 \mathrm{bp}$ in length, comprising 13 protein-coding genes (PCGs), 22 transfer RNAs (tRNAs), two ribosomal RNAs (rRNAs), and one putative control region with a length of 318 bp (Figure 1).

The mitochondrial genome structure is detailed in Table 3. Gene order and orientation are similar to the previous earthworm mitochondrial genomes (Boore and Brown 1995; Zhang et al. 2015) but slightly smaller and more condensed (with several intergenic overlaps, see Table 3). The gene organization is similar to other earthworm species (e.g. Lumbricus terrestris: Boore and Brown 1995).

The nucleotide composition is asymmetric $(31.9 \% \mathrm{~A}, 27.9 \% \mathrm{~T}, 14.9 \% \mathrm{G}$, and $25.3 \%$ for $\mathrm{C}$ ) with an overall $\mathrm{A}+\mathrm{T}$ content of $59.9 \%$. One remarkable trait of metazoan mitogenomes is the strand-specific bias in nucleotide composition (Hassanin et al. 2005; Reyes et al. 1998). Such bias is measured as $\mathrm{G} / \mathrm{C}$-skew $(\mathrm{G} \%-\mathrm{C} \%) /(\mathrm{G} \%+\mathrm{C} \%)$ and A/T-skew (A\%-T\%)/(A\%+T\%), respectively (Perna and Kocher 1995). The overall GC- and AT-skews of the H-strand of P. corethrurus mitogenome were -0.258 and 0.066 , respectively, indicating a compositional bias associated with an excess of $\mathrm{C}$ over $\mathrm{G}$ nucleotides and a slight excess of A over T nucleotides on the $\mathrm{H}$-strand. 


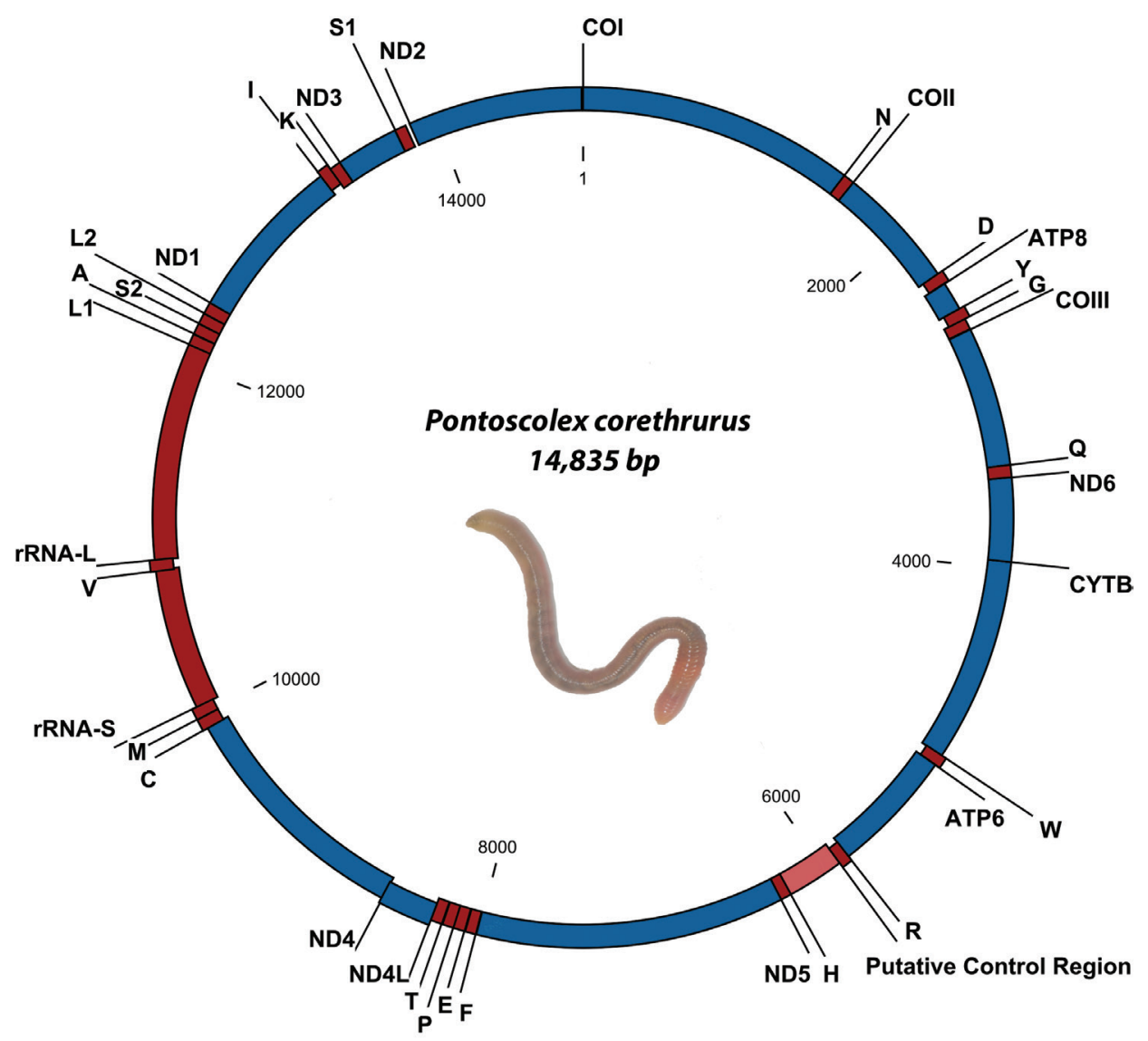

Figure I. The mitochondrial genome of Pontoscolex corethrurus (Müller, 1857). Gene order and positions are shown, including the putative control region. IUPAC single letter codes are used to identify transfer RNA. The L1, L2, S1, and S2 transfer RNAs are differentiated on the basis of their anti-codons TAG, TAA, TCT, and TGA, respectively.

\section{Protein-coding genes}

The $P$. corethrurus genome contained the expected 13 protein-coding genes with a total of 11,131 bp in size, accounting for $75.03 \%$ of the whole mitogenome. Most of the PCGs are initiated with ATG codons, except for ND3 gene, which uses GTG as the initiation codon. Six PCGs (COX1, ATP8, COX3, ND6, ND3, and ND2) are terminated with an incomplete codon $\mathrm{T}$ or $\mathrm{TA}$, which could be completed to TAA by polyadenylation posttranscriptionally (Ojala et al. 1981). COX2 and ND1 use TAG as a termination codon.

Nucleotide composition and codon usage frequencies were calculated from a concatenated sequence of all protein-coding genes on the $\mathrm{H}$-strand. The base composition of protein-coding genes revealed a negative bias for A (14.4\%), especially at second codon positions $(12.9 \%$, Table 4). For all protein genes, $\mathrm{T}$ was the most frequent nucleotide at the first and third positions whereas $\mathrm{G}$ was most frequent at the second position. 
Table 3. Organisation and structure of the $P$. corethrurus mitochondrial genome.

\begin{tabular}{|c|c|c|c|c|c|c|c|c|}
\hline Gene & Direction & From & To & $\begin{array}{l}\text { Size } \\
\text { (bp) }\end{array}$ & Start & Stop & $\begin{array}{l}\text { Anti- } \\
\text { codon }\end{array}$ & $\begin{array}{c}\text { Intergenic bases } \\
\text { (bp) }\end{array}$ \\
\hline COX1 & + & 1 & 1540 & 1540 & ATG & T-- & & 0 \\
\hline tRNA-Asn & + & 1541 & 1602 & 62 & & & GTT & 0 \\
\hline COX2 & + & 1603 & 2289 & 687 & ATG & TAG & & -1 \\
\hline tRNA_Asp & + & 2289 & 2351 & 63 & & & GTC & 2 \\
\hline ATP8 & + & 2354 & 2513 & 160 & ATG & T-- & & 0 \\
\hline tRNA-Tyr & + & 2514 & 2576 & 63 & & & GTA & -1 \\
\hline tRNA_Gly & + & 2576 & 2638 & 63 & & & TCC & 3 \\
\hline COX3 & + & 2642 & 3419 & 778 & ATG & T-- & & 0 \\
\hline tRNA_Gln & + & 3420 & 3488 & 69 & & & TTG & 0 \\
\hline ND6 & + & 3489 & 3954 & 466 & ATG & T-- & & 0 \\
\hline Cytb & + & 3955 & 5094 & 1140 & ATG & TAA & & -2 \\
\hline tRNA-Trp & + & 5092 & 5154 & 63 & & & TCA & 1 \\
\hline ATP6 & + & 5156 & 5851 & 696 & ATG & TAA & & -2 \\
\hline tRNA_Arg & + & 5850 & 5910 & 61 & & & TCG & 0 \\
\hline Putative Control Region & + & 5911 & 6228 & 318 & & & & \\
\hline tRNA-His & + & 6229 & 6288 & 60 & & & GTG & 0 \\
\hline ND5 & + & 6289 & 8010 & 1722 & ATG & TAA & & 3 \\
\hline tRNA_- ${ }^{\text {Phe }}$ & + & 8014 & 8073 & 60 & & & GAA & 4 \\
\hline tRNA_Glu & + & 8078 & 8141 & 64 & & & TTC & 0 \\
\hline tRNA_Pro & + & 8142 & 8204 & 63 & & & TGG & 4 \\
\hline tRNA-Thr & + & 8209 & 8272 & 64 & & & TGT & 0 \\
\hline ND4L & + & 8273 & 8569 & 297 & ATG & TAA & & -7 \\
\hline ND4 & + & 8563 & 9921 & 1359 & ATG & TAA & & -2 \\
\hline tRNA-Cys & + & 9920 & 9986 & 67 & & & GCA & 1 \\
\hline tRNA- ${ }^{\mathrm{Met}}$ & + & 9988 & 10050 & 63 & & & CAT & -1 \\
\hline s-rRNA & + & 10050 & 10838 & 789 & & & & -7 \\
\hline tRNA-Val & + & 10832 & 10894 & 63 & & & TAC & -2 \\
\hline 1-rRNA & + & 10893 & 12104 & 1212 & & & & 0 \\
\hline tRNA-Leu 1 & + & 12105 & 12166 & 62 & & & TAG & 2 \\
\hline tRNA- ${ }^{\mathrm{Ala}}$ & + & 12169 & 12230 & 62 & & & TGC & 1 \\
\hline tRNA-Ser 2 & + & 12232 & 12293 & 62 & & & TGA & 1 \\
\hline tRNA- ${ }^{\text {Leu } 2}$ & + & 12295 & 12360 & 66 & & & TAA & 0 \\
\hline ND1 & + & 12361 & 13290 & 930 & ATG & TAG & & -1 \\
\hline tRNA_lle & + & 13290 & 13354 & 65 & & & GAT & 0 \\
\hline tRNA_Lys & + & 13355 & 13417 & 63 & & & TTT & 0 \\
\hline ND3 & + & 13418 & 13770 & 353 & GTG & TA- & & -1 \\
\hline tRNA-Ser 1 & + & 13770 & 13832 & 63 & & & TCT & 0 \\
\hline ND2 & + & 13833 & 14835 & 1003 & ATG & T-- & & 0 \\
\hline
\end{tabular}

\section{Ribosomal and transfer RNA genes}

Like other mitochondrial genomes (Inoue et al. 2000; Zardoya et al. 1995), twentytwo tRNA genes were identified (Supplementary figure 1). The tRNA genes were scattered throughout the mitochondrial genome and ranged in size from 60 to $67 \mathrm{bp}$ 


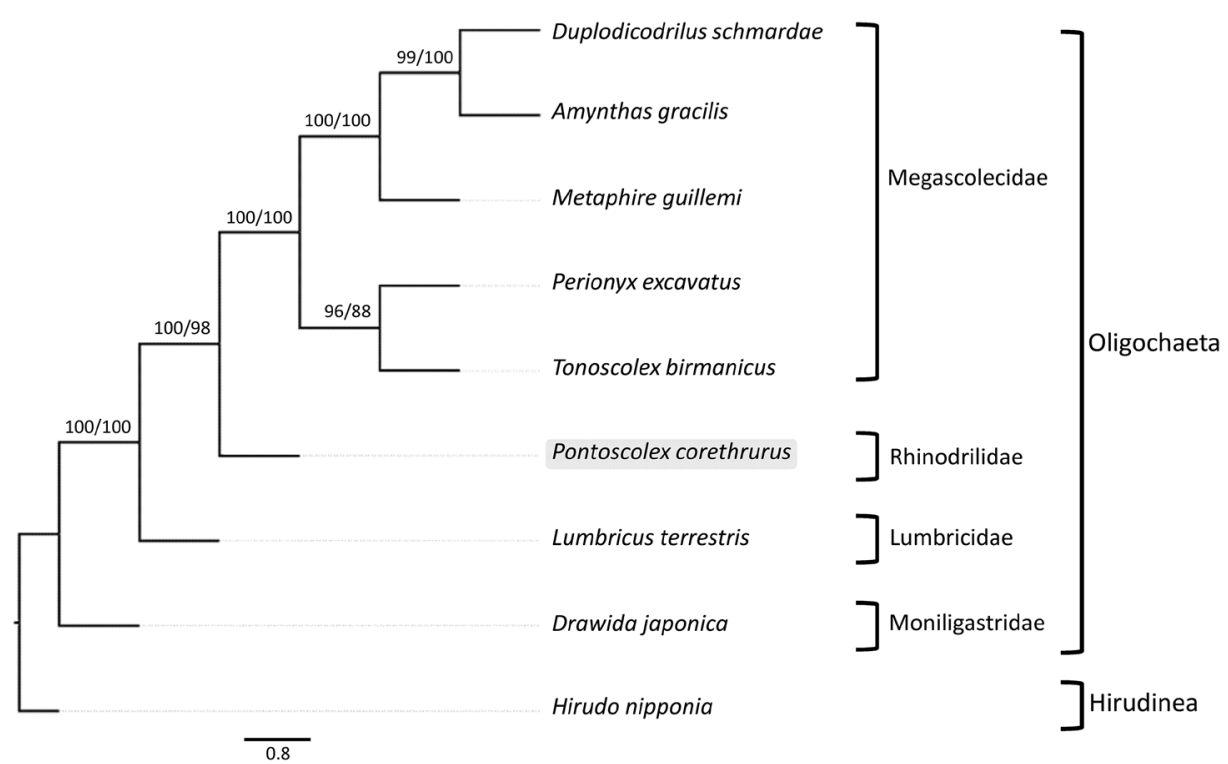

Figure 2. Phylogenetic relationships among phylum Annelida based on the combined 13,416 bp nucleotide positions. Total alignment length is greater than the combined $P$. corethrurus protein coding and rRNA sequence lengths due to overlapping protein coding sequences that are subsequently concatenated, and indel regions in the alignment. The posterior probability value of $\mathrm{BI}$ analyses and bootstrap support values of ML analyses (in the order: BI, ML) are indicated near the branches.

(Table 3). The $P$. corethrurus mitogenome also contained a small subunit of rRNA and a large subunit of rRNA, which were $789 \mathrm{bp}$ and $1212 \mathrm{bp}$ in length, respectively. As in other Clitellata genomes, these genes were located between the tRNA ${ }^{\mathrm{Met}}$ and $\mathrm{tRNA}^{\mathrm{Val}}$ genes and between tRNA ${ }^{\text {Val }}$ and tRNA ${ }^{\text {Leu }}$ genes, respectively (Zhang et al. 2016b).

\section{Non-coding regions}

As shown in Table 3 , there are 22 intergenic spacer regions, ranging in size from -7 to 4 bp observed in P. corethrurus.

As in most Clitellata, the major non-coding region in P. corethrurus mitochondrial genome was located between tRNA-Arg and tRNA-His. It was determined to be $318 \mathrm{bp}$ in length, less than other reported Clitellata species (Zhang et al. 2016a), and it had a base composition that was rich in $\mathrm{A}$ and $\mathrm{T}(\mathrm{A}+\mathrm{T}=67.6 \%)$.

\section{Phylogenetic analyses within the Clitellata}

The phylogenetic trees (the 50\% majority-rule consensus tree is shown in Figure 2) were highly consistent regardless of the analytic method used, and were statistically 
Table 4. Base composition for protein-coding, tRNA, and rRNA genes of $P$. corethrurus mitogenome.

\begin{tabular}{|c|c|c|c|c|c|c|}
\hline \multirow{2}{*}{ Gene/Region } & \multicolumn{4}{|c|}{ Base composition (\%) } & \multirow{2}{*}{$A+T(\%)$} & \multirow{2}{*}{ Size (bp) } \\
\hline & $\mathbf{T}$ & $\mathrm{C}$ & A & G & & \\
\hline COX1 & 27.4 & 26.7 & 27.9 & 18.1 & 55.3 & 1,540 \\
\hline COX2 & 25.8 & 24.3 & 34.9 & 15.0 & 60.7 & 687 \\
\hline ATP8 & 24.4 & 26.9 & 36.9 & 11.9 & 61.3 & 160 \\
\hline COX3 & 27.3 & 27.5 & 25.7 & 19.5 & 53.0 & 778 \\
\hline ND6 & 28.3 & 26.0 & 30.3 & 15.5 & 58.6 & 466 \\
\hline Cytb & 28.0 & 27.1 & 29.7 & 15.3 & 57.6 & 1,140 \\
\hline ATP6 & 29.6 & 29.2 & 30.6 & 10.6 & 60.2 & 696 \\
\hline ND5 & 27.7 & 26.7 & 31.7 & 13.9 & 59.4 & 1,722 \\
\hline ND4L & 25.9 & 28.3 & 33.0 & 12.8 & 58.9 & 297 \\
\hline ND4 & 27.5 & 27.5 & 32.3 & 12.7 & 59.8 & 1,359 \\
\hline ND1 & 28.4 & 25.8 & 29.8 & 16.0 & 58.2 & 930 \\
\hline ND3 & 32.6 & 26.1 & 27.2 & 14.2 & 59.8 & 353 \\
\hline ND2 & 30.0 & 28.2 & 30.7 & 11.1 & 60.7 & 1,003 \\
\hline \multicolumn{7}{|l|}{ Protein Coding } \\
\hline $1 \mathrm{st}$ & 30.2 & 25.4 & 17.4 & 27.0 & 47.6 & 3,710 \\
\hline $2 s t$ & 24.9 & 27.6 & 12.9 & 34.6 & 37.8 & 3,710 \\
\hline $3 s t$ & 36.1 & 27.9 & 13.8 & 22.3 & 49.8 & 3,710 \\
\hline Total & 30.4 & 27.0 & 14.7 & 28.0 & 45.1 & 11,131 \\
\hline tRNA & 30.5 & 17.6 & 34.9 & 17.0 & 65.5 & 1,391 \\
\hline rRNA & 24.1 & 22.0 & 37.6 & 16.3 & 61.7 & 2,001 \\
\hline Putative Control Region & 31.5 & 18.9 & 36.2 & 13.5 & 67.6 & 318 \\
\hline Overall & 28.1 & 25.6 & 31.8 & 14.6 & 59.9 & 14,835 \\
\hline
\end{tabular}

supported by high posterior probability and intermediate bootstrap values. This phylogenetic analysis represented the first investigation of $P$. corethrurus relationships within the Clitellata based on the complete mitogenome. As indicated by the tree, different species from the same family clustered together (Megascolecidae: M. guillemi, D. schmardae, A. gracilis, P. excavatus and T. birmanicus), and the species from Lumbricidae and the $P$. corethrurus formed a monophyletic group. The species $D$. japonica belongs to the Moniligastridae, the sister group to Crassiclitellata (earthworms), which explains its phylogenetic position. The Moniligastridae are not Crassiclitellata because they have a single cell layer in the clitellum.

\section{Conclusion}

For the first time, the sequencing, annotation and analysis of the mitochondrial genome of a member of Rhinodrilidae was completed. The mitogenome of $P$. corethrurus was found to be $14,835 \mathrm{bp}$ in length and showed a similar composition in size, low GC content and gene order to earthworm mitogenomes already available. The complete mitogenome reported here is expected to allow for further studies of the P. corethrurus phylogeny and for analyses on the taxonomic status of the family Rhinodrilidae. 


\section{Declaration of interest section}

The authors report no conflicts of interest and are responsible for the content and writing of the paper.

\section{Acknowledgments}

We thank Jose Talavera for the taxonomic identification of the studied specimen. This study was financially supported by the Portuguese Government (FCT project PTDC/ AAC-AMB/ 115713/2009). Luis Cunha was supported by an EU Marie Curie fellowship - MSCA-IF-2014-GF-660378. George Brown, Elodie da Silva acknowledge fellowship support by CNPq. Ana Caroline Conrado was supported by a scholarship funded by CAPES. Sam James was supported by USA NSF award DEB-1136604. Dave Stanton was supported by a NERC grant (NE/M017656/1).

\section{References}

Anderson S, Bankier AT, Barrell BG, De Bruijn M, Coulson AR, Drouin J, Eperon I, Nierlich D, Roe BA, Sanger F (1981) Sequence and organization of the human mitochondrial genome. Nature, 290: 457-465. https://doi.org/10.1038/290457a0

Bernt M, Donath A, Jühling F, Externbrink F, Florentz C, Fritzsch G, Pütz J, Middendorf M, Stadler PF (2013) MITOS: Improved de novo metazoan mitochondrial genome annotation. Molecular Phylogenetics and Evolution 69:313-319. https://doi.org/10.1016/j. ympev.2012.08.023

Bhattacharjee G, Chaudhuri P (2002) Cocoon production, morphology, hatching pattern and fecundity in seven tropical earthworm species—a laboratory-based investigation. Journal of Biosciences 27: 283-294. https://doi.org/10.1007/BF02704917

Blakemore R, Ito M, Kaneko N (2006) Alien earthworms in the Asia/Pacific region with a checklist of species and the first records of Eukerria saltensis (Oligochaeta: Ocnerodrilidae) and Eiseniella tetraedra (Lumbricidae) from Japan, and Pontoscolex corethrurus (Glossoscolecidae) from Okinawa. Assessment and Control of Biological Invasion Risks: 173-181.

Boore JL (1999) Animal mitochondrial genomes. Nucleic Acids Research 27: 1767-1780. https://doi.org/10.1093/nar/27.8.1767

Boore JL, Brown WM (1995) Complete sequence of the mitochondrial DNA of the annelid worm Lumbricus terrestris. Genetics 141: 305-319.

Brown GG, James SW, Pasini A, Nunes DH, Benito NP, Martins PT, Sautter KD (2006) Exotic, peregrine, and invasive earthworms in Brazil: diversity, distribution, and effects on soils and plants. Caribbean Journal of Science 42: 339.

Buch AC, Brown GG, Niva CC, Sautter KD, Lourençato LF (2011) Life cycle of Pontoscolex corethrurus (Müller, 1857) in tropical artificial soil. Pedobiologia 54: S19-S25. https://doi. org/10.1016/j.pedobi.2011.07.007 
Buch AC, Brown GG, Niva CC, Sautter KD, Sousa JP (2013) Toxicity of three pesticides commonly used in Brazil to Pontoscolex corethrurus (Müller, 1857) and Eisenia andrei (Bouché, 1972). Applied Soil Ecology 69: 32-38. https://doi.org/10.1016/j.apsoil.2012.12.011

Chapuis-Lardy L, Brauman A, Bernard L, Pablo A-L, Toucet J, Mano M, Weber L, Brunet D, Razafimbelo T, Chotte J-L (2010) Effect of the endogeic earthworm Pontoscolex corethrurus on the microbial structure and activity related to $\mathrm{CO}_{2}$ and $\mathrm{N}_{2} \mathrm{O}$ fluxes from a tropical soil (Madagascar). Applied Soil Ecology 45: 201-208. https://doi.org/10.1016/j.apsoil.2010.04.006

Cunha L, Montiel R, Novo M, Orozco-terWengel P, Rodrigues A, Morgan AJ, Kille P (2014) Living on a volcano's edge: genetic isolation of an extremophile terrestrial metazoan. Heredity 112: 132-142. https://doi.org/10.1038/hdy.2013.84

Da Silva E, Nahmani J, Lapied E, Alphonse V, Garnier-Zarli E, Bousserrhine N (2016) Toxicity of mercury to the earthworm Pontoscolex corethrurus in a tropical soil of French Guiana. Applied Soil Ecology 104: 79-84. https://doi.org/10.1016/j.apsoil.2015.11.018

Dupont L, Decaëns T, Lapied E, Chassany V, Marichal R, Dubs F, Maillot M, Roy V (2012) Genetic signature of accidental transfer of the peregrine earthworm Pontoscolex corethrurus (Clitellata, Glossoscolecidae) in French Guiana. European Journal of Soil Science 53: 70-75. https://doi.org/10.1016/j.ejsobi.2012.09.001

Felsenstein J (1985) Confidence limits on phylogenies: an approach using the bootstrap. Evolution 39: 783-791. https://doi.org/10.1111/j.1558-5646.1985.tb00420.x

Hamoui V (1991) Life-cycle and growth of Pontoscolex corethrurus (Müller, 1857)(Oligochaeta, Glossoscolecidae) in the laboratory. Revue D'écologie Et de Biologie du Sol 28: 469-478.

Hassanin A, Léger N, Deutsch J (2005) Evidence for multiple reversals of asymmetric mutational constraints during the evolution of the mitochondrial genome of Metazoa, and consequences for phylogenetic inferences. Systematic Biology 54: 277-298. https://doi. org/10.1080/10635150590947843

Inoue JG, Miya M, Tsukamoto K, Nishida M (2000) Complete mitochondrial DNA sequence of the Japanese sardine Sardinops melanostictus. Fisheries Science 66: 924-932. https://doi. org/10.1046/j.1444-2906.2000.00148.x

James SW (2012) Re-erection of Rhinodrilidae Benham, 1890, a senior synonym of Pontoscolecidae James, 2012 (Annelida: Clitellata). Zootaxa 3540: 67-68.

James SW, Davidson SK (2012) Molecular phylogeny of earthworms (Annelida: Crassiclitellata) based on 28S, $18 \mathrm{~S}$ and $16 \mathrm{~S}$ gene sequences. Invertebrate Systematics 26: 213-229. https://doi.org/10.1071/IS11012

Kumar S, Stecher G, Tamura K (2016) MEGA7: Molecular Evolutionary Genetics Analysis version 7.0 for bigger datasets. Molecular Biology and Evolution, msw054. https://doi. org/10.1093/molbev/msw054

Lavelle P, Barois I, Cruz I, Fragoso C, Hernandez A, Pineda A, Rangel P (1987) Adaptive strategies of Pontoscolex corethrurus (Glossoscolecidae, Oligochaeta), a peregrine geophagous earthworm of the humid tropics. Biology and Fertility of Soils 5: 188-194. https://doi. org/10.1007/BF00256899

Lowe TM, Eddy SR (1997) tRNAscan-SE: a program for improved detection of transfer RNA genes in genomic sequence. Nucleic Acids Research 25: 955-964. https://doi.org/10.1093/ nar/25.5.0955 
Marichal R, Martinez AF, Praxedes C, Ruiz D, Carvajal AF, Oszwald J, del Pilar Hurtado M, Brown GG, Grimaldi M, Desjardins T (2010) Invasion of Pontoscolex corethrurus (Glossoscolecidae, Oligochaeta) in landscapes of the Amazonian deforestation arc. Applied Soil Ecology 46: 443-449. https://doi.org/10.1016/j.apsoil.2010.09.001

Müller F (1857) II.-Description of a new species of Earth-worm (Lumbricus corethrurus). Journal of Natural History 20: 13-15. https://doi.org/10.1080/00222935709487865

Nylander J (2004) MrModeltest v2. Program distributed by the author. Evolutionary Biology Centre, Uppsala University 2.

Ojala D, Montoya J, Attardi G (1981) tRNA punctuation model of RNA processing in human mitochondria. Nature 290: 470-474. https://doi.org/10.1038/290470a0

Perna NT, Kocher TD (1995) Patterns of nucleotide composition at fourfold degenerate sites of animal mitochondrial genomes. Journal of Molecular Evolution 41: 353-358. https:// doi.org/10.1007/BF01215182

Reyes A, Gissi C, Pesole G, Saccone C (1998) Asymmetrical directional mutation pressure in the mitochondrial genome of mammals. Molecular Biology and Evolution 15: 957-966. https://doi.org/10.1093/oxfordjournals.molbev.a026011

Righi G (1984) Pontoscolex (Oligochaeta, Glossoscolecidae), a new evaluation. Studies on Neotropical Fauna and the Environment 19: 159-177. https://doi.org/10.1080/01650528409360653

Ronquist F, Huelsenbeck JP (2003) MrBayes 3: Bayesian phylogenetic inference under mixed models. Bioinformatics 19: 1572-1574. https:/doi.org/10.1093/bioinformatics/btg180

Sambrook J, Russell D (2001) Molecular Cloning: A Laboratory Manual 2nd edn. Cold Spring Harbor Laboratory Press, New York. https://doi.org/10.1093/jhered/92.4.371

Xia X, Xie Z (2001) DAMBE: software package for data analysis in molecular biology and evolution. Journal of Heredity 92: 371-373.

Zardoya R, Garrido-Pertierra A, Bautista JM (1995) The complete nucleotide sequence of the mitochondrial DNA genome of the rainbow trout, Oncorhynchus mykiss. Journal of Molecular Evolution: 942-951. https://doi.org/10.1007/BF00173174

Zhang L, Jiang J, Dong Y, Qiu J (2015) Complete mitochondrial genome of four pheretimoid earthworms (Clitellata: Oligochaeta) and their phylogenetic reconstruction. Gene 574: 308-316. https://doi.org/10.1016/j.gene.2015.08.020

Zhang L, Jiang J, Dong Y, Qiu J (2016a) Complete mitochondrial genome of an Amynthas earthworm, Amynthas aspergillus (Oligochaeta: Megascolecidae). Mitochodrial DNA Part A 27: $1876-1877$.

Zhang L, Sechi P, Yuan M, Jiang J, Dong Y, Qiu J (2016b) Fifteen new earthworm mitogenomes shed new light on phylogeny within the Pheretima complex. Scientific Reports: 6. https://doi.org/10.1038/srep20096

Zhao L, Gao T, Lu W (2015) Complete mitochondrial DNA sequence of the endangered fish (Bahaba taipingensis): Mitogenome characterization and phylogenetic implications. ZooKeys 546: 181-195. https://doi.org/10.3897/zookeys.546.5964 


\section{Supplementary material I}

Inferred secondary structure of 22 tRNA genes in the mitochondrial DNA of the pantropical earthworm Pontoscolex corethrurus (Rhinodrilidae, Clitellata).

Authors: Ana C. Conrado, Hugo Arruda, David W.G. Stanton, Samuel W. James, Peter Kille, George Brown, Elodie Silva, Lise Dupont, Shabnam Taheri, Andrew J. Morgan, Nelson Simões, Armindo Rodrigues, Rafael Montiel8, Luis Cunha

Data type: molecular data

Copyright notice: This dataset is made available under the Open Database License (http://opendatacommons.org/licenses/odbl/1.0/). The Open Database License $(\mathrm{ODbL})$ is a license agreement intended to allow users to freely share, modify, and use this Dataset while maintaining this same freedom for others, provided that the original source and author(s) are credited.

Link: https://doi.org/10.3897/zookeys.688.13721.suppl1 